\title{
Microeconomic Firm Characteristics and Long Run Returns: The Case of Firms That Issued Equity at Nairobi Securities Exchange
}

\author{
Martin Khoya Odipo, Tobias Olweny and Oluoch Oluoch \\ Jomo Kenyatta University of Agriculture and Technology, Nairobi, Kenya \\ Email: odipomk@yahoo.com
}

\begin{abstract}
This study looks at micro-economic determinants of long run performance of shares issued in Nairobi Securities Exchange from 1st Jan. 2007 to 31st Dec.2013. Do these selected microeconomic determinants have statistically significant effects on long run return on equity issued in the Nairobi security exchange in Kenya? The study has a total 12 firms that issued shares in the security exchange during this period. In order to achieve the objectives of the study "a calendar study" approach on the issued shares was adopted. Monthly average returns were calculated for a period of 5 years. Nine hypotheses were deduced and executed. Three were based on benchmarks namely: Nairobi Securities Exchange Index (NSEI), Capital Asset Pricing Model (CAPM) and Matching Firms (MF). Along with the 3 mentioned measurement models, other 6 micro-economic variables were incorporated in the study; firm size, offer size, stock turnover, book/ market ratio, age and quality of underwriter. A panel data multi-regression and single regression analysis were run to examine the relationship between average return and micro-economic determinants on firm performance in the long run. The results of the study showed that the study corresponds with some of results of the previous studies with regard to the long run returns of either under or over performance. The level of under of over performance based on the benchmarks used were that NSEI and Matching firms performed better than firms that issued equity. However firms that issued equity performed better than CAPM as bench mark. The study also revealed that two explanatory variables; Age and Quality of underwriter were statistically significant as determinants of long run performance. Finally two independent variables were found to have positive influence on firms that issued equity in the NSE. In conclusion this study confirmed the results of previous studies done either supporting certain variables as determinants of long run return or do not support certain variables as determinants of long run return.
\end{abstract}

Keywords: public offerings, long run return, firm characteristics, initial public offering, seasoned equity offering, share issue privatization.

\section{Introduction}

Long run return on equity issued by firms has remained a controversial topic in finance. In finance literature, the empirical studies have shown that those firms that issue equity perform poorly in the long run. This feature can discourage listed firms from seeking equity financing and instead seek bank lending. However following the financial crises of 2008 this argument has been put question. The financial crisis of 2008 led capital financing by banks to reduce loan financed growth (Aiyar, Calomiris \& Wieladek, 2014; Giovannini, Mayer, Micossi, Noia, Onado, Pagano \&Polo, 2015). Therefore equity financing requires a second look in as far as long run return is concerned. The study focuses on micro-economic factors as firm characteristics to unveil the empirical paradox on shares issued as IPO, SEO and SIP and their long run return. This study considers firm characteristics which include firm size, firm age, firm share turnover, offer size, book/market ratio, and quality of underwriter in each of these firms. The study poses the following questions: How would these firms perform in comparison to the three benchmarks; securities market index (NSEI), matching firms (MF) and Capital asset pricing model (CAPM)? Which of these microeconomic variables have statistically significant influence on the long run return on firms that issue equity in the Nairobi Securities Exchange (NSE) market? Would the assessment of benchmark return for equity issue be important in the determination of long run return? 
What influence would these characteristics have on the long run return on these firms following corporate event such as shares issued at the NSE? Why do different studies give different results where firms issue equity?

The study is in line with previous studies done in this area but with emphasis on financial market performance rather than operating performance of these firms as a measurement tool. The research adopts both cross sectional and time series approach in measuring the performance of the long term average return on Nairobi Securities Exchange equity issues. A study of average return must compare realized returns to certain benchmarks of normal returns. An important focus of this paper is that it addresses several methodological issues. First given that average returns are sensitive to measurement methods (Fama, 1998; Lyon, Barber \&Tsai, 1999; Mitchel \& Stafford, 2000).Secondly testing significance of average return (AR) using bootstrapped- skewness to adjust t -statistics. Thirdly testing the market timing theory where firms issue equity in stock markets to maximize cash proceeds at the expense of uninformative disclosure, a dominant feature in USA stock market (Capstaff \& Flettcher, 2011).

The remainder of article is structured as follows. Section two reviews the literature regarding firm characteristics on long run return. Section three describes the data applied and discusses methodology used. Section four presents the results based on both single and multivariate analyses. Section five concludes and discusses possibilities of future research areas on the subject.

\section{Literature Review}

Important theories have been discussed in relation to equity issue which include; market timing theory by Baker and Wurgler (2002); efficient market theory Fama (1970, 1976) liquidity preference theory Keynes (1936) and Agency theory Jensen and Meckling (1976). These theories form the basis of this paper.

The market timing theory by Barker and Wurgler (2002) states that in practice firms issue equity when market is bullish so that many firms that issue equity may maximize their cash inflow from shares issued. Graham and Harvey (2001) argue that most managers' actions are determined by market timing when raising capital. As consequence of this, many firms may invest in projects with low returns which results in low long turn return. In capital markets that are inefficient, market timing benefits only shareholders who would dispose of their shares after a short time. This is at the expense of long term shareholders like Institutional shareholders and new entrants. To safeguard long term investors and new entrants against this problem, investors look for quality of underwriter based on certification hypothesis by Corwin and Shultz (2005) in the case of new equity issues. This hypothesis suggests that reputable underwriters are associated with reduced uncertainty. Managers too have incentives in market timing if they think that it is possible to please the outgoing shareholders. Baker and Wurgler (2002) raise four points that may lead managers to time their issue. First, firms tend to issue equity instead of debt when stock market value is high. Secondly firms tend to issue equity when cost of equity is relatively low and in countries where repurchase of equity is permissible the cost of purchase is low. In certain cases, issues are done when investors are enthusiastic about future earnings prospects of the firm. Lastly it is believed that market timing is based on market surveys done through market intelligence by managers. According to Capstaff and Fletcher (2011), U.K. Managers have less incentive to produce misleading or uninformative disclosures which border on timing the market unlike in cases found in USA firms. These short comings may lead to malfunctioning of microeconomic determinants in equity issue and subsequent long run return.

Fama $(1970,1976)$ argued that conditions of market equilibrium could only be stated in terms of expected returns based on mathematical concepts of expected value to status not implied by the general notion of market efficiency. Therefore it is believed that if determinants of future returns in the securities markets were extremely efficient then they can reflect information about individual stocks and about markets as a whole. Lathan (1986) argues that security markets are efficient with respect to information if disclosing that set of information to all agents would not change equilibrium price of the portfolio. Under this argument a firm that is to raise additional capital in the market should disclosure important information in the market such as offer size, undistorted book/market ratio. Mamaysky and Wang (2001) however argued that this information is not necessary in this age of technology and that 
future returns from securities can be predicted using statistical techniques. However this line of argument has not been supported empirically. It is common to find markets which are inefficient thus leading to market failures. As a result these market failures non-functionality of microeconomic variables are possible.

Keynes (1936) developed the liquidity preference theory where he argued that investors would expect higher returns when period of their investment is long and lower returns when period of investments are short. Investments in equity is generally long term therefore the returns should exceed 91 day Treasury bill rates. Another aspect of liquidity is how quickly an investor can dispose the investment. This is also seen in stock markets. Some shares are disposed quickly where as other shares are difficult to dispose depending on the nature of the underlying assets which means such firms have low stock turnover and have big book/market ratio. The book to market ratio attempts to identify undervalued or overvalued securities. A high ratio is preferred by value managers who interpret it to mean that the company is a value stock that is trading cheaply in the market compared to its book value. High book/market ratio may be an indicator of higher long run return.

A firm's performance in stock market may be explained by Agency theory. Jensen and Meckling (1976) argue that there are two competing interests in a firm; namely shareholders and agents (directors). Chen, Li, Shapiro and Zhang(2013) also brings in a new dimension of two types of shareholders; shareholders whose desire is quick returns and exit the firm as opposed to shareholders who have long term interest in the firm.

We categorize empirical analyses into six parts in line with microeconomic variables covering firm size, offer size, stock turnover, age of the firm, quality of underwriters and book/market ratio subsequent to offering. Several scholars have conducted studies relating to firm performance following equity issue to determine how equity performs in the long run and have come out with varying results. Some have indicated that in the long run, firms that issue equity underperform certain bench marks (Ahmad-Zaluki \& Lim, 2012; Kooli \& Serut, 2004; Corwin, 2003; Lyon, Barber \& Tsai, 1999). Others have shown in their studies that firms that issue equity over perform such set of bench marks (Thomas, Jiao \&Yew, 2011; Choi, Lee \& Megginson, 2010; Dang \& Yang, 2007). Moreover, other studies give results indicating that performance varies with period of issue (Schaub \& Highfield, 2004). These contradictory results put into question whether in the investors' point of view they need to have strategies in order to trade in securities market or successfully time when to invest in the securities market in order to avoid long term losses. This study looks at long run performance of firms that have issued equity in line with the following microeconomic variables; firm size, offer size, firm stock turnover, book/market ratio, quality of underwriter and firm age.

Bessemblier and Zhang (2013) argue that, based on firm size, market value can explains positive abnormal return. Smallest firms account for largest negative abnormal returns (Vithessonthi \& Tonguria, 2015; Ritter, 1991). Berk (1995) finds market value of firm has an explanatory power of the return. Lack of information available about small firms causes these firms to have fewer investors than firms with wide range of information (Autore, Bray \& Peterson, 2010). Pandey (2015) argues that large firms are likely to possess economies of scale as compared to their smaller counter parts. Al -Shawardi \& AlTarawei (2015) find that there is significant relationship between firm size and long run performance. Khurshed, Marc Goergen \& Mudambi (2007) find that large firms have better performance in the long run. The same result is found in a study by Khrushed (1999) where he concludes that the larger the size of the firm the better is the long-run performance. However Jegadeesh (2000) finds that firm size is insignificant to firm's performance.

Offer size is the number of shares offered at a time. Large issues generate more investor interest leading to more analysis by market participants and better long run performance of the firm. Ritter (1991) examined the long run performance of initial public offerings (IPOs) in USA market. His objective for the study was to determine whether the IPOs were overpriced. A sample of 1,526 IPOs in USA market in1975-1984 period was selected. To evaluate the long run performance two measures were used; the cumulative average adjusted return (CAAR), three year buy and hold (BHAR) returns for both the IPOs and a set of matching firms. The matching firms were represented by firms quoted in AMEX and NYSE. The matching firms were equated to market value. These firms were segmented by gross proceeds of the offer. Cross Sectional and Time Series analysis was used. The results of the study indicated that the smaller offers had worst under performance within the three years following issues. 
Large size issues may also create positive sentiment (Belghitar and Dixion, 2012). However this might lead to poor long run performance where shares are used to raise capital without considering viability of the projects where raised funds have to be used. The amount of offer has certain effects. Large issues are typically done by more established firms. A given firm will choose to float a larger issue when the market conditions are characterized by strong demand (Ritter, 1991). Ghosh (2005); Choi, Lee, and Megginson (2010); Belghitar and Dixion (2012); Minardi, Ferrariand and Araujo-Travares (2013) find positive relationship between offer size and long run performance. However, Lee, Lochhead, Ritter and Zhao (1996); Cai, Liu and Mase (2008); Thomadakis, Nounis and Gounopoulas (2012) find a statistically significant but negative relationship between issue size and long run perform.

Stock turnover is the volume of shares traded in a particular given period. It is used as a measure of stock liquidity. Stock liquidity is measured by dividing the total number of shares traded over a year by the average number of shares outstanding for that year. The higher the share turnover, the more liquid the shares of the company are. Share turnover ratio tells an investor how easily the shares can be disposed of but it does not indicate the performance of a firm (Merritt, 2017). Chord, Subrahmanyam and Anshman (2001) find a significant cross-sectional relation between stock turnover and the variability of liquidity when using trading volume and turnover as a measure of liquidity. Liu (2010) however finds that stock turnover as a measure of liquidity has no predictive power for long run return.

Book to Market ratio is the ratio of cash flow proxy to current price level (Kothari \& Shanken, 1997; Pontiff \& Schall, 1998). Dividing a cash flow proxy by current market price produces a variable that is correlated with future returns. Book to Market ratio of individual stocks has ability to explain cross sectional variation in stock return. Brav and Gompers (1997) find a strong positive relationship between average long run return to book / market ratio. However Berk (1995) does not find market book/market ratio as having any positive effect on firm's run return.

Under writers play an important role on long run performance when firms issue equity in Stock market. Underwriters advise their client firms on offer timing, pricing decisions and distribution of shares to investors. Where a firm hires a reputable underwriter it serves as a signal for the firm's quality of issuance, consequently mitigating adverse selection costs which are common in equity offering process (Slovin, Sushka \& Lai, 2000). The quality of underwriter is determined by the variable Sponsor. The variable Sponsor is measured by "The Annual Broker Survey" in United Kingdom generally referred to as (Corwin and Schultz Rank). In USA underwriter reputation is determined by the market share of the underwriter in any particular year's total underwriting proceeds rank). Autore, Bray and Peterson (2009) document that prospectus information helps to predict SEO post offer performance and that good information is provided by reputable underwriter. The lead manager performs the due diligence in respect to information disclosed in the offer documents. The quality of disclosure in the prospectus will depend on the quality of the underwriter involved in the issue (McLean, Zhang, \& Zhao, 2011). The certification hypothesis suggests that reputable underwriters are associated with reduced uncertainty (Corwin \& Schultz, 2005). Suzuki and Yamada (2012) find that the quality of underwriter has significant positive influence on firm's long run performance. The same result is found by Chahine and Filatotchev (2008) and Silva and Bilinski (2015) who all argue that the presence of a reputable underwriter enhances effectiveness because due diligence performed is and state that SEOs underwritten by high-quality brokers show no evidence of underperformance. However, Su and Bangasa (2011) in the Chinese Stock Market find no significant influence of under writer reputation on long run return on the equity issued.

Firm age can be a proxy for risk. Age can be a measure of both uncertainty and investor optimism (Ritter, 1991). The age of a firm is measured by number of years it has been in existence before going public or when it issues SEO. Age of a firm is associated with experience, intensity of knowledge and entrepreneurial flexibility (Chen, Li, Shapiro \&Zhang, 2013). A firm that has been in operation for many years is able to sustain risk. A firm which has been in business for a long time is well known and there is little element of uncertainty (Lowry, Officer\& Schewert, 2008; Alvarez, 2015). Ritter (1991), Belghitar \& Dixon (2012) document a more pronounced positive relationship between issuer age and long run performance of IPOs. This is also found in a study done by (Khurshed, 1999). These scholars argue that this positive relationship is because older firms have less information asymmetry. However in other studies (Brau, Couch \& Sutton, 2012; Liu, Uchida \& Gao, 2012) report an insignificant negative relationship between firm's age and long run performance of IPOs. 


\section{Developing Null Hypotheses, Data and Methodology}

\subsection{Developing Null Hypothesis}

Average returns were computed, there after average returns were compared with the long run returns in respect to; NSEI, CAPM and Matching Firms as benchmarks employed. A set of null hypotheses were developed to test if AR was statistically different from zero. Another set of null hypotheses were developed to test the relationship between AR of firms that issued equity with firm characteristics represented by firm size, offer size, stock turnover, age, quality of underwriter and book/market ratio. These hypotheses were aimed at answering the study objectives namely;

- How do these microeconomic variables perform in comparison to the three benchmarks in the long run?

- Would the assessment of benchmark return for equity issue be important in the determination of long run return?

- Which of these microeconomic variables have statistically significant influence on the long run return on firms that issue equity in the Nairobi Securities Exchange?

- What influence would these firm characteristics have on long run return on firms that issue equity in the stock market?

- Why do different studies give different results?

Table 1. Null hypotheses

\begin{tabular}{|c|c|c|c|}
\hline & & Hypothesis number & The Null Hypothesis \\
\hline \multirow{3}{*}{ BENCHMARKS: } & Benchmark 1: AR & $\begin{array}{l}\text { H01 Nairobi Security } \\
\text { Exchange Index }\end{array}$ & $\begin{array}{l}\text { Long run AR is not significantly different } \\
\text { from }{ }_{04} \text { zero based on (NSEI) as benchmark }\end{array}$ \\
\hline & Benchmark 2: AR & $\begin{array}{l}\mathrm{H}_{02} \text { Matching firm } \\
(\mathrm{MF})\end{array}$ & $\begin{array}{l}\text { Long run AR is not significantly different } \\
\text { from zero based on (MF) as a benchmark }\end{array}$ \\
\hline & Benchmark 3: AR & $\begin{array}{l}\mathrm{H}_{03} \text { Capital Asset } \\
\text { Pricing Model (CAPM) }\end{array}$ & $\begin{array}{l}\text { Long run AR is not significantly different } \\
\text { from zero based on (CAPM) as a benchmark }\end{array}$ \\
\hline
\end{tabular}

Table 2. Firm characteristics

\begin{tabular}{|c|c|c|}
\hline Firm size & $\mathrm{H}_{04}$ & There is no significant relationship size and its long run between firm performance \\
\hline Offer Size & $\mathrm{H}_{05}$ & $\begin{array}{l}\text { There is no statistical significant relationship between offer size and its long run } \\
\text { performance }\end{array}$ \\
\hline Stock t/over & $\mathrm{H}_{06}$ & $\begin{array}{l}\text { There is no statistical significant relationship between Stock turnover and its long } \\
\text { run performance }\end{array}$ \\
\hline $\mathrm{Bk} / \mathrm{Mk}$ ratio & $\mathrm{H}_{07}$ & $\begin{array}{l}\text { There is no statistical significant relationship between firm's Book/Market ratio } \\
\text { and its long run performance. }\end{array}$ \\
\hline Age & $\mathrm{H}_{08}$ & $\begin{array}{l}\text { There is no statistical significant relationship between Age of a firm and its long } \\
\text { run performance. }\end{array}$ \\
\hline Underwriter quality & $\mathrm{H}_{09}$ & $\begin{array}{l}\text { There is no statistical significant relationship between firm size and its long run } \\
\text { performance }\end{array}$ \\
\hline
\end{tabular}

\subsection{Data and Methodology}

This study used a sample of 12 firms that issued equity in Nairobi Securities Exchange over a period from 1st Jan. 2007- 31st Dec 2013. Each firm was subjected to 5 years of statistical analysis. The study used a panel data analysis to determine which of the firm characteristics has statistically significant effect on firm performance in the long run. Firm performance was measured by abnormal return (AR) as influenced by these firm characteristics relative to certain benchmarks.

The three bench marks were employed in the study to assess abnormal return. These included: 


\section{i. Nairobi Securities Exchange}

This represent the general index weighted by market capitalization of 20 leading firms in the market. The return of firms that issued shares were compared with NSE 20 share index.

$$
\mathrm{AR}=\mathrm{R}_{\mathrm{it}}-\mathrm{R}_{\mathrm{mt}}
$$

\section{ii. Matching firms}

As with Ritter (1991), Spiess and Affleck-Graves (1995), Laughran and Ritter (1997), we paired each issuing firm with non-issuing firm based on the closest but with higher market value of equity. This benchmark used market returns of firms that issued equity and matched with firms that did not issue equity. The size was based on market capitalization. The abnormal return (AR) according to the benchmark shall be:

$$
\mathrm{AR}_{\mathrm{fm}}=\mathrm{R}_{\mathrm{it}}-\mathrm{R}_{\mathrm{MF}}
$$

where

$\mathrm{AR}_{\mathrm{it}}$ : return of company i in calendar period $\mathrm{t}$.

$\mathrm{R}_{\mathrm{MF}}$ : return of the matching firm in calendar period $\mathrm{t}$.

\section{iii. Capital Asset Pricing Model}

Capital asset pricing model assumes that the market is perfect and all the risky assets are tradable stocks which are available to all interested investors. It is composed of a risk free asset rate (rf). CAPM also assumes that all information is available including a covariance, variances, and mean rate of return of stocks.

This benchmark uses the monthly returns $\left(\mathrm{R}_{\mathrm{it}}\right)$ during the study period for the firms that issued equity shares. The monthly risk free rate $\left(\mathrm{R}_{\mathrm{ft}}\right)$ represented by 91 day treasury bills return which are collected from Central Bank of Kenya. The market monthly return during the study period $\mathrm{R}_{\mathrm{mt}}$ is taken from the NSE index weighted by market capitalization. This is given in the model below:

where:

$$
\mathrm{R}_{\mathrm{it}}-\mathrm{R}_{\mathrm{f}}=\beta\left(\mathrm{R}_{\mathrm{mt}}-\mathrm{R}_{\mathrm{ft}}\right)
$$

$\mathrm{R}_{\mathrm{it}}=$ the return of company (firm that issued equity) in the calendar period.

$\mathrm{R}_{\mathrm{mt}}=$ the return of market in calendar period measured by NSE 20 share index.

$\mathrm{R}_{\mathrm{ft}}=$ the 91 day Treasury bill return in calendar period.

$\beta=$ the CAPM $\beta$ using correlation coefficient (beta factor).

where $\beta=\frac{n\left[\sum x y\right]-\left[\sum x \sum y\right]}{n\left[\sum x^{2}\right]-\left[\sum x\right]^{2}}$

$\mathrm{X}=$ monthly market index (NSE)

$\mathrm{Y}=$ monthly return for each firm that issued equity

\subsubsection{Regression models}

The study used the following model to evaluate each of firm characteristics to the long run return on firms that issued equity. A panel data regression was used to test the relationship between the microeconomic determinants and firm performance (AR). Panel data included repeated measures of one or more variables on one or more firms which includes both cross-sectional and time series data. The micro- economic model is specified as follows:

where:

$$
\mathrm{Y}=\alpha+\mathrm{b}_{1} \mathrm{X}_{1}+\mathrm{b}_{2} \mathrm{X}_{2}+\mathrm{b}_{3} \mathrm{X}_{3}+\mathrm{b}_{4} \mathrm{X}_{4}+\mathrm{b}_{5} \mathrm{X}_{5}+\mathrm{b}_{6} \mathrm{X}_{6}+\dot{\varepsilon}
$$

$\mathrm{Y}=$ Average return

$\alpha=$ constant

$\mathrm{b}=$ beta coefficient

$\mathrm{X}_{1}=$ Firm size

$\mathrm{X}_{2}=$ Offer size

$\mathrm{X}_{3}=$ Firm share turnover

$\mathrm{X}_{4}=$ Age

$\mathrm{X}_{5}=$ Book/ Market ratio 
$\mathrm{X}_{6}=$ Quality of Underwriter

$\dot{\varepsilon}=$ Error term

The study used Hausman test to determine whether to use fixed effect model or random effect model. The study found that in most cases fixed effect model was appropriate.

Table 3. Definitions of variables for the study

\begin{tabular}{|c|c|}
\hline \multicolumn{2}{|c|}{ Panel A: Definition of variables related to benchmarks } \\
\hline 1. Nairobi Securities Exchange Index & $\begin{array}{l}\text { The annual return of the market represented by the (NSE) general index } \\
\text { weighted by market capitalization. }\end{array}$ \\
\hline 2. Matching Firm (MF) & $\begin{array}{l}\text { The firms that exist in the market and of same age, same size, as } \\
\text { compared to those firms that issued equity in the NSE market. }\end{array}$ \\
\hline 3. Capital Asset Pricing Model & $\begin{array}{l}\text { Equation combining market return, 91day treasury bill rates, and return } \\
\text { from individual firms }\end{array}$ \\
\hline \multicolumn{2}{|c|}{ Panel B: Definition of variables related to firm characteristics } \\
\hline 1. Firm size & $\begin{array}{l}\text { Firm size is the market capitalization when the firm issues equity up to } \\
\text { the next five }\end{array}$ \\
\hline 2. Offer size & The market capitalization when shares are issued \\
\hline 3. Stock turnover & The \\
\hline 4. Book/Market ratio & The book value of a firm divided by its market value for each period \\
\hline 5. Quality of underwriter & $\begin{array}{l}\text { The total proceeds that are paid to underwriter over the period when } \\
\text { issues are made }\end{array}$ \\
\hline 6. Age of the firm & Number of years since the firm was founded. \\
\hline
\end{tabular}

\subsubsection{Test of significance on Average Return (AR)}

Following the calculation of AR against the employed benchmarks; NSE, Matching Firm and CAPM the parametric one sample t-test is used to examine whether the resulting CAR is significantly different from zero at a significant level $(\alpha \leq 5 \%)$. The following hypotheses were used:

$\mathrm{H}_{01}$ : AR sample, $\mathrm{NSE}=0$ against $\mathrm{H}_{01}: \mathrm{AR}$ sample. $\mathrm{NSE} \neq 0$

$\mathrm{H}_{02}$ : AR sample, $\mathrm{MF}=0$ against $\mathrm{H}_{02}: \mathrm{AR}$ sample $\mathrm{MF} \neq 0$

$\mathrm{H}_{03}$ : $\mathrm{AR}$ sample, $\mathrm{CAPM}=0$ against $\mathrm{H}_{03}: \mathrm{AR}$ sample $\mathrm{CAPM} \neq 0$

A further test was done to investigate the effect of the firm's characteristics on the abnormal return. Using multi-linear regression model was constructed to find out how these factors were correlated with AR based on the three bench marks above. The null hypotheses below were tested on the regression model and results were based on significant level $(\mathrm{p} \leq 5 \%)$.

$\mathrm{H}_{04}$ : firm size, $\mathrm{AR} \leqslant 5 \%$ against $\mathrm{H}_{1,4}$ firm size, $\mathrm{AR}>5 \%$

$\mathrm{H}_{05}$ : offer size, $\mathrm{AR} \leqslant 5 \%$ against $\mathrm{H}_{1,5}$ offer size, $\mathrm{AR}>5 \%$

$\mathrm{H}_{06}$ : stock turnover, $\mathrm{AR} \leqslant 5 \%$ against $\mathrm{H}_{1,6}$ stock turnover, $\mathrm{AR}>\%$

$\mathrm{H}_{07}$ : firm age, $\mathrm{AR} \leqslant 5 \%$ against $\mathrm{H}_{1,7}$ firm age, $\mathrm{AR}>5 \%$

$\mathrm{H}_{08}$ : firm book/market ratio, $\mathrm{AR} \leqslant 5 \%$ against $\mathrm{H}_{1,8}$ firm book/market ratio, $\mathrm{AR}>5 \%$

$\mathrm{H}_{09}$ : Quality of underwriter, $\mathrm{AR} \leqslant 5 \%$ against $\mathrm{H}_{1,9}$ Quality of underwriter, $\mathrm{AR}>5 \%$

\section{Empirical Results}

The Nairobi Securities Exchange monthly returns were calculated for the period of study. Alongside the monthly NSE, each of the three bench marks (NSE 20 share index, Matching firms \& CAPM) monthly returns were calculated to make the comparison. The discussion is based on each benchmark results when analyzing the long run return.

\subsection{Descriptive Statistics}

The table below presents descriptive statistics for sample used in the analysis. The sample includes 12 firms that issued equity during the period of study. 
Table 4. Descriptive statistics

\begin{tabular}{llllll}
\hline Statistics & Firm size & Offer size & Age & Stock Turnover & Book/Market ratio \\
\hline Mean & $4.95 \mathrm{E}+10$ & $1.73 \mathrm{E}+10$ & 37.91667 & $2 . .76 \mathrm{E}+08$ & 5.813036 \\
Median & $6.28 \mathrm{E}+09$ & $2.22 \mathrm{E}+08$ & 42.0000 & 44617300 & 1.25 \\
Maximum & $1.82 \mathrm{E}+12$ & $2.00 \mathrm{E}+08$ & 57.0000 & $3.78 \mathrm{E}+09$ & 90.375 \\
Minimum & 54810000 & 1000000 & 11.00000 & 1946880 & 0.00037 \\
Std. Dev. & $2.34 \mathrm{E}+11$ & $5.56 \mathrm{E}+10$ & 14.84644 & $6.78 \mathrm{E}+08$ & 14.68796 \\
Skewness & 7.321194 & 3.0119068 & -0.76588 & 3.633645 & 3.95287 \\
Kurtosis & 55.66903 & 10.07911 & 2.119435 & 16.17960 & 20.44706 \\
Observations & 60 & 60 & 60 & 60 & 60 \\
\hline
\end{tabular}

Table 4 above shows the descriptive statistics of the independent variables. The skewness of variables should be 0 and kurtosis not more than 3. For skewness only age is around 0 whereas kurtosis age as a variable approaches 3

\subsection{Long Run Performance of Equity Issued Compared to Three Benchmarks}

\subsubsection{NSE as a benchmark}

Table 5. Sample results based on NSE benchmark

\begin{tabular}{lcccccc}
\hline & \multicolumn{6}{c}{ Test Value $=0$} \\
\cline { 2 - 7 } & \multirow{2}{*}{$\mathrm{T}$} & Df & Sig. (2-tailed) & Mean Difference & $\begin{array}{c}\text { 95\% Confidence Interval of the Difference } \\
\text { Lower }\end{array}$ & Upper \\
\hline NSEI & -1.188 & 59 & .240 & -12.7055300 & -34.104234 & 8.693174 \\
$\mathrm{R}_{\text {it }}$ (Firm Return) & -1.223 & 59 & .226 & -13.2508400 & -34.931116 & 8.429436 \\
\hline
\end{tabular}

In the above Table 5 NSEI is used as a benchmark, it shows that t values of NSEI and Firm Return have AR which are negative suggesting that both of them have values less than 0 . Therefore the null hypothesis is rejected and the alternative hypothesis accepted. Although both returns show negative returns $\mathrm{R}_{\mathrm{it}}$ shows a worse return as compared to NSEI firms that issued based on the mean difference. Therefore it can be concluded that firms that issued equity performed poorer than NSEI return.

\subsubsection{Matching firm as a benchmark}

Table 6. Sample results based on MF benchmark

\begin{tabular}{lcccccc}
\hline & \multicolumn{6}{c}{ Test Value $=0$} \\
\cline { 2 - 6 } & \multirow{2}{*}{$\mathrm{T}$} & Df & Sig. (2-tailed) & Mean Difference & $\begin{array}{c}\text { 95\% Confidence Interval of the Difference } \\
\text { Lower }\end{array}$ & Upper \\
\hline Matching & -1.010 & 59 & .316 & -11.0708400 & -32.993383 & 10.851703 \\
$\mathrm{R}_{\text {it }}$ (Firm Return) & -1.223 & 59 & .226 & -13.2508400 & -34.931116 & 8.429436 \\
\hline
\end{tabular}

In the above Table 6, Matching Firm is used as a benchmark and its shows that the $t$ values of Matching Firm and Firm Return have negative ARs suggesting that both of them have values less than 0 . Therefore the null hypothesis is rejected and the alternative hypothesis accepted. The Matching Firms have performed better than firms that issued equity at the periods of study as indicated by mean difference. 


\subsubsection{Benchmark CAPM}

Table 7. Sample results based on CAPM benchmarks

\begin{tabular}{lcccccc}
\hline & \multicolumn{6}{c}{ Test Value $=0$} \\
\cline { 2 - 7 } & $\mathrm{T}$ & Df & Sig. (2-tailed) & Mean Difference & $\begin{array}{c}\text { 95\% Confidence Interval of the Difference } \\
\text { Lower }\end{array}$ & Upper \\
\hline CAPM & -2.620 & 59 & .011 & -184.592650 & -325.575356 & -43.609944 \\
$\mathrm{R}_{\text {it }}$ (Firm Return) & -1.223 & 59 & .226 & -13.2508400 & -34.931116 & 8.429436 \\
\hline
\end{tabular}

In the above Table 7, CAPM is used as a benchmark and it shows that the $t$ values of CAPM return and Firm Return have AR are both negative suggesting that both of them have values less than 0 . Therefore the null hypothesis is rejected and the alternative hypothesis accepted. However Rit return difference where CAPM has a larger negative mean difference than the firms that issued equity.

\subsection{Bivariate Panel Regression Results (Test of Null Hypotheses from H04--H09)}

Bivariate panel regression presented in table 8 indicates that quality of underwriter and age of the firm are statistically significant in influencing firm returns. For example, quality of underwriter is statistically significant at $5 \%$ level and has positive effect on AR (CAPM). The result implies the AR (CAPM) firm return is more likely to improve by $6.15 \%$ when the quality of underwriter improves.

Table 8. Simple linear regression of AR with firm characteristics

\begin{tabular}{cccccccccc}
\hline $\begin{array}{c}\text { Independent } \\
\text { variables }\end{array}$ & Benchmarks & $\mathbf{R}$ & $\mathbf{R} 2$ & $\mathbf{A}$ & $\boldsymbol{\beta}$ & $\begin{array}{c}\text { t-stat } \\
\text { z-stat }\end{array}$ & ( $\boldsymbol{\alpha})$ sig & $(\boldsymbol{\beta})$ sig & F-stat \\
\hline \multirow{5}{*}{ Firm size } & $\mathrm{AR}(\mathrm{NSE})$ & 0.02 & 0.0004 & 131.647 & .6567861 & 0.15 & 0.193 & 0.884 & 0.8843 \\
& $\mathrm{AR}(\mathrm{CAPM})$ & 0.03 & 0.0009 & 873.5414 & 6.671977 & 0.22 & 0.190 & 0.822 & 0.8224 \\
& $\mathrm{AR}(\mathrm{MF})$ & 0.00264 & 0.0007 & 3.627754 & .0226151 & 0.20 & 0.157 & 0.843 & 0.8430 \\
\hline \multirow{5}{*}{ Offer size } & $\mathrm{AR}(\mathrm{NSE})$ & 0.01414 & 0.0002 & 140.1573 & .3221014 & 0.09 & 0.035 & 0.925 & 0.9254 \\
& $\mathrm{AR}(\mathrm{CAPM})$ & 0.01 & 0.0001 & 996.4342 & 0.359549 & 0.06 & 0.023 & 0.952 & 0.9522 \\
& $\mathrm{AR}(\mathrm{MF})$ & 0.01 & 0.0001 & 4.039859 & .0048418 & 0.06 & 0.016 & 0.956 & 0.9556 \\
\hline \multirow{5}{*}{ Stock turnover } & $\mathrm{AR}(\mathrm{NSE})$ & 0.05567 & 0.0031 & 97.88463 &. .705349 & 0.42 & 0.394 & 0.672 & 0.6717 \\
& $\mathrm{AR}(\mathrm{CAPM})$ & 0.04582 & 0.0021 & 757.0624 & 0.82475 & 0.35 & 0.317 & 0.725 & 0.7246 \\
& $\mathrm{AR}(\mathrm{MF})$ & 0.05385 & 0.0029 & 2.953275 & .0658784 & 0.41 & 0.309 & 0.683 & 0.6834 \\
\hline \multirow{5}{*}{ Book/Market } & $\mathrm{AR}(\mathrm{NSE})$ & 0.10247 & 0.0105 & 142.932 & .5784364 & 0.79 & 0.000 & 0.432 & 0.4323 \\
& $\mathrm{AR}(\mathrm{CAPM})$ & 0.08888 & 0.0079 & 1003.116 & 0.306702 & 0.68 & 0.000 & 0.496 & 0.4962 \\
& $\mathrm{AR}(\mathrm{MF}$ & 0.07071 & 0.0050 & 4.073468 & .0100883 & 0.54 & 0.000 & 0.589 & 0.5894 \\
\hline \multirow{5}{*}{ Underwriter } & $\mathrm{AR}(\mathrm{NSE})$ & 0.17607 & 0.031 & 139.0626 & 0.1593 & 1.36 & 0.000 & 0.173 & 0.1731 \\
& $\mathrm{AR}(\mathrm{CAPM})$ & 0.27055 & 0.0732 & 949.1261 & 0.0615 & 2.14 & 0.000 & 0.032 & 0.0323 \\
& $\mathrm{AR}(\mathrm{MF})$ & & 0.0580 & 3.881831 & 0.251406 & 1.89 & 0.000 & 0.059 & 0.0588 \\
\hline \multirow{3}{*}{ Age of firm } & $\mathrm{AR}(\mathrm{NSE})$ & 0.04123 & 0.0017 & -698.7361 & 0.28652 & 2.85 & 0.023 & 0.006 & 0.0065 \\
& $\mathrm{AR}(\mathrm{CAPM})$ & 0.03464 & 0.0012 & -4163.544 & 0.7705 & 2.62 & 0.041 & 0.012 & 0.0117 \\
& $\mathrm{AR}(\mathrm{MF})$ & & 0.0013 & -16.83847 & 0.5530704 & 2.78 & 0.030 & 0.008 & 0.0077 \\
\hline
\end{tabular}

On table 8 above, firm size is positively correlated with average return. The $\mathrm{R}^{2}$ values are $(0.04 \%)$ where NSE is used as a benchmark, $(0.09 \%)$ when using CAPM as a benchmark and $(0.07 \%)$ when using Matching Firm as a benchmark. These are low values meaning that they can only explain very small variances of AR. The model is highly statistically insignificant at $5 \%$ level of significance $(t=0.884$, $0.822,0.843)$ in comparison to the respective benchmarks. Therefore the null hypothesis is not rejected at $5 \%$ level of significance. The result is in line with studies that were done in the past (Jagadeesh, 2000)

The second characteristic is offer size. It is positively correlated with abnormal return. The $\mathrm{R}^{2}$ values are $(0.02 \%)$ when using NSE as a benchmark, (0.01\%) when using CAPM as a benchmark and $(0.01 \%)$ when using Matching Firm as a benchmark. These are low values meaning that they can only explain 
very small variances of AR. The model is highly statistically insignificant (t statistics with significance level at $5 \%=0.925,0.952,0.956$. The null hypothesis $\left(\mathrm{H}_{05}\right)$ is not rejected at $5 \%$ level of significance. These results are similar to the results of the study by (Thomadakis, Nounis \& Gounopoulas, 2012).

The third characteristic is Stock turnover. It is positively correlated with abnormal return. The $\mathrm{R}^{2}$ values are $(0.32 \%)$ when NSE is used as a benchmark, $(0.21 \%)$ when CAPM is used as benchmark and $(0.29 \%)$ when Matching Firm is used as a benchmark. These are low values meaning that they can only explain very small variances of AR. The model is highly statistically insignificant at $5 \%$ level of significance $(\mathrm{sig}=0.925,0.952,0.956)$. The null hypothesis $\left(\mathrm{H}_{06}\right)$ is not rejected at $5 \%$ level of significance. The results are similar to those of previous studies by (Liu, 2010; Merrit, 2017).

The fourth characteristic is Book/Market ratio. It is positively correlated with abnormal return. The $\mathrm{R}^{2}$ values are $(1.05 \%)$ NSE is used as a benchmark, $(0.79 \%)$ when CAPM is used as a benchmark and $(0.5 \%)$ when Matching Firm is used as a benchmark. These are very low values meaning that they can only explain very small variances of AR. The model is highly statistically insignificant at $5 \%$ level of significance $(\mathrm{sig}=0.432,0.496,0.589)$. Thus null hypothesis $\left(\mathrm{H}_{07}\right)$ is not rejected at $5 \%$ level of significance. This result confirms the findings by (Berk, 1995).

The fifth characteristic is quality of underwriter. It is positively correlated with abnormal return. The $\mathrm{R}^{2}$ values are $(3.1 \%)$ when using NSE as a benchmark, (7.32\%) when using CAPM as a benchmark and (5.8\%) when using Matching Firm as a benchmark. These are low values but they can explain $16 \%$ variances of AR. The model has a mixture of statistically significance at $5 \%$ level (sig. $=0.173,0.032$, 0.058, ). The null hypothesis $\left(\mathrm{H}_{08}\right)$ is not totally rejected at $5 \%$ level of significance. This study finds quality of underwriter a determinant of long run return and is in line with previous studies done by (Silva \& Blinski, 2015;Suzuki \&Yamada, 2012; Chahine \&Filatotchev, 2008)

The sixth characteristic which is age of the firm is positively correlated with abnormal return. The $\mathrm{R}^{2}$ values are $(0.17 \%)$ when using NSE as a benchmark, $(.12 \%)$ when using CAPM as a benchmark and $(.12 \%)$ when using Matching Firm as a benchmark. These are low values but that they can explain only $16 \%$ variances of AR. The model is statistically significant at $5 \%$ level of significance ( $\mathrm{sig}=0.006,0.012$, 0.008). The null hypothesis $\left(\mathrm{H}_{09}\right)$ is rejected at $5 \%$ level of significance. This study finds Age as a significant determinant of long run return on firms that issue equity in the NSE. The result is in conformity with studies previously done by (Belghitar \& Dixion, 2012; Khurshed, 1999; Ritter, 1991)

\subsection{Regression Model}

The study used a panel data analysis to establish the relationship between average return and the micro economic determinants (variables).

Table 9. Multi-regression results

\begin{tabular}{lllllll}
\hline $\mathrm{R}_{\text {it }}$ Firm return & Co-ef. & Std. error & $\mathrm{T}$ & $\mathrm{p}>|\mathrm{t}|$ & {$[95 \%$ conf. } & Interval $]$ \\
\hline Age & 58.49915 & 9.002442 & 6.49 & 0.000 & 40.27049 & 76.60591 \\
Book/Market & 1.231886 & 1.105379 & 1.11 & 0.271 & -.9999577 & 3.462631 \\
$\operatorname{lnFs}$ & -6.536092 & 7.499615 & -0.87 & 0.388 & -21.67092 & 8.598754 \\
$\operatorname{lnOs}$ & 39.00817 & 74.44263 & 0.52 & 0.603 & -111.2231 & 189.2395 \\
$\operatorname{lnST}$ & 5.921376 & 11.50907 & 0.51 & 0.610 & -17.30407 & 29.14762 \\
Q/underwriter & 186.8745 & 30.27558 & 6.27 & 0.000 & 125.7759 & 247.9731 \\
$\quad$ Con & -2977.001 & 1365.477 & -2.18 & 0.035 & -5732.646 & -221.3567 \\
\hline F test that all & $\mathrm{U}$ i-o & $\mathrm{F}(11,42)$ & -4.80 & & Prob. $>\mathrm{F}=0.0001$ & \\
\hline
\end{tabular}

Table 9 above shows the level of significance for each independent variable at $5 \%$ level of significance. Age of the firms issuing equity along with the quality of underwriter are statistically significant. Other independent variables such as book/market ratio, firm size, offer size and stock return are statistically insignificant based on average return. The results confirm what is found in single linear regression on table 8 . 
Table 10. Hypothesis test results

\begin{tabular}{|c|c|c|c|}
\hline & Hypothesis Number & The Null Hypothesis & Results \\
\hline Benchmark & $\begin{array}{l}\text { Benchmark number one: NSEI } \\
\text { AR (H01) }\end{array}$ & $\begin{array}{l}\text { The abnormal return is not significantly different } \\
\text { from zero once NSE is applied as a benchmark }\end{array}$ & Rejected \\
\hline Benchmark & $\begin{array}{l}\text { Benchmark number two: MF } \\
\text { AR (H02) }\end{array}$ & $\begin{array}{l}\text { The abnormal return is not significantly different } \\
\text { from zero once MF is applied as a benchmark }\end{array}$ & Rejected \\
\hline Benchmark & $\begin{array}{l}\text { Benchmark number three: CAPM } \\
\text { AR (H03) }\end{array}$ & $\begin{array}{l}\text { The abnormal return is not significantly different } \\
\text { from zero when CAPM is applied as a } \\
\text { benchmark }\end{array}$ & Rejected \\
\hline \multirow{6}{*}{$\begin{array}{l}\text { Independent } \\
\text { Variables }\end{array}$} & Firm Size (H04) & $\begin{array}{l}\text { There is no statistical significant relationship } \\
\text { between firm size of listed firm and its long run } \\
\text { return }\end{array}$ & Not rejected \\
\hline & Offer Size (H05) & $\begin{array}{l}\text { There is no statistical significant relationship } \\
\text { between offer size of listed firm and its long run } \\
\text { return }\end{array}$ & Not Rejected \\
\hline & Stock return (H06) & $\begin{array}{l}\text { There is no statistical significant relationship } \\
\text { between stock return of listed firm and its long } \\
\text { run return }\end{array}$ & Not rejected \\
\hline & Book/Market ratio (H07) & $\begin{array}{l}\text { There is no statistical significant relationship } \\
\text { between book/market ratio of listed firm and its } \\
\text { long run return }\end{array}$ & Not Rejected \\
\hline & Underwriter (H08) & $\begin{array}{l}\text { There is no statistical significant relationship } \\
\text { between quality of underwriter of listed firm and } \\
\text { its long run return }\end{array}$ & Rejected \\
\hline & Age (H09) & $\begin{array}{l}\text { There is no statistical significant relationship } \\
\text { between age of the firm and its long run return }\end{array}$ & Rejected \\
\hline
\end{tabular}

\section{Summary and Conclusion}

\subsection{Summary}

The study looked at micro economic variables in relation to long run return on 12 firms that issued equity in the Nairobi Securities Exchange during 2007-2013. The study applied three benchmarks namely NSEI, Matching Firms and CAPM. Panel data multi-regression technique and single regression analysis were used to examine the relationship between average return and micro-economic determinants on firm performance for these firms that issued equity.

NSEI and Matching Firms benchmarks performed better than firms that issued equity. However the issuing firms performed better than CAPM as benchmark. Both single regression and multi-regression methods applied in the study found that only age and quality of underwriters were statistically significant variables in determination of long run return.

\subsection{Conclusion and Further Areas of Research}

This study shows that certain variables have statistically significant effect on long run return on equity issues in the Nairobi Securities Exchange. The study recommends that a longer period of study should be undertaken, this may give more insight into how these variables may influence on long run return. Secondly a further study should include more micro-economic variables.

\section{References}

1. Ahamad-Zaluki, N., \& Lim, B.K. (2012). "The Investment performance of Mesdaq market Initial public offering," Asian Academy of management Journal of Accounting and Finance8:1, 1-23. 
2. Aiyar, S., Calomiris, C.W. \& Wieladek, T. (2014) "Does Macro-Prudential Regulation Leak? Evidence from a UK policy Experiment" Journal of Money, Credit and Banking Vol. 46 (1) 181-214.

3. Al-Shawawreh, F., \& Al-Tarawneh, O. (2015). "Firm Characteristics and long run abnormal returns after IPOs: A Jordanian Financial Market Experience," International Journal of Economics and Finance

4. Alvarez, S. (2015) "Pricing IPOs: An Approach for Spanish firms," Journal of Finance and banking Management, 3 (1) 60-76.

5. Autore, M., Bray, D.E. \& Peterson, D.R. (2009) "Intended use of proceeds and the long run performance of seasoned equity issues," Journal of Corporate Finance Vol. 15 (3) 358-36\%.

6. Belghitar, Y., Dixion, R. (2012) "Do venture Capitalists reduce underpricing and underperformance of IPOs," Applied Economics Vol. 22 (1) 33-44

7. Berk, J. (1995) "A critique of size related anomalies," Review of Financial studies (8)275- 286.

8. Bessembinder, H. \& Zhang. F. (2013) "Firm Characteristics and long run stock return after corporate event," Journal of Financial Economics Vol. 109, (91) 83- 102

9. Brau, J.C., Couch, R.B., \& Sutton, N.K. (2012) "The desire to acquire and IPO long run under performance," Journal of Financial and Quantitative Analysis 47 (3) 391-413.

10. Brav, A., \& Gompers, P.A. (1997). "Myth or Reality? The long run under performance of initial public offerings: Evidence from venture and non-venture capital backed companies," Journal of Finance 52, 1791-1821

11. Cai, X., Liu, G. \& Mase, B. (2008) "Long run performance of initial public offerings and its determinants: The case of China," Review of Quantitative Finance and Accounting 30 (4) 419-432.

12. Capstaff, J. \& Flettcher, J. (2011) "Long term performance and choice of SEO method by U.K. firms," Journal of Business Finance and Accounting Vol.38: 1262-1289.

13. Chahine, S. \& Filatotchev I.,(2008) "The effects of Venture Capitalist affiliation to under writer on short and long term performance in French IPOs," Global Finance Journal 18 (3) 351-373.

14. Chen, V., Li, J., Shapiro, D. \& Zhang, X. (2014) "Ownership Structure and innovation: An Emerging Market Perspective," Asia Pacific Journal of Management 31, 1- 24

15. Choi, S.D.; Lee, I. \& Megginson, W. (2010) "Do privatization IPOs out perform in the Long run?" Financial Management, spring 2010, 153-185.

16. Chordia, T., Roll, R., \& Subrahmanyam, A. (2001). "Commonality in liquidity." Journal of Financial Economics, 56, 3-28.

17. Corwin, S.A. (2003) "The Determinant of under Pricing for seasoned equity offers," Journal of Finance Vol. LVIII, 5.

18. Corwin, S.A., \& Schultz, P. (2005) "The Role of Underwriting Syndicate: Pricing, Information Production, and Underwrite Competition," The Journal of Finance, Vol. LX No 1.

19. Dang, L., \& Yang, J. J. (2007) The choice between rights and underwritten equity evidence from Chinese Stock Markets, Oregon State University, Unpublished, working papers.

20. Fama, E.F. 1970) "Efficient Capital markets: a review of theory and empirical work," Journal of Finance Vol. 25 (2) $383-417$

21. Fama, E.F (1976) "Efficient Capital markets," Journal of Finance Vol.31 (1) 143-145.

22. Fama, E.F. (1998) "Market Efficiency, Long term Returns and Behavioral Finance," Journal of Financial Economics, 49:283-306.

23. Giovannini, A., Mayer, C, Micossi, S., Di Noia, C., Onado, M., Pagano,M., and Polo, A. (2015) "Restarting European Long term investment Finance," Green Paper Discussion Document. Center for Economic Policy Research (CEPR)

24. Graham, J.R., \& Harvey, R. (2001). "The Theory and Practice of Corporate Finance: Evidence from the Field," Journal of Financial Economics, Vol. 60: 187-243.

25. Gregory, A.; Cuermat, C. \& Al -Shawawreh, F. (2010) "Long run returns, behavioral timing and pseudo timing," Journal of Business Finance and Accounting 37 (5-6) 612-64\%.

26. IPOs and SEOs traded as American depository receipts: Does timing matter?" Journal of Asset Management, 263-271.

27. Jegadeesh, N. (2000) "Long -term performance of seasoned equity offering: Benchmark errors and biases in expectations," Financial Management, Vol.29, 5-30.

28. Khurshed, A. (1999) "The long run performance of IPOs," Managerial Finance 33, (6) 401-419.

29. Khushed, A. Mudambi, R. Goergen, M., (2007). "The long-run performance of UK IPOs: Can it be predicted?" Journal of Managerial Finance, Vol. 33, 6, 401-419. 
30. Kooli, M. \& Suret, J. (2004) "The aftermarket performance of Initial public Offering in Canada," Journal of Multinational Financial Management 14 (1) 47-66

31. Kothari, S.P. \& Shanken, J. ( 1997) "Book to Market, dividend yield and expected market return: A time series analysis," Journal of Financial Economics 44, 169- 203.

32. Lee, I., Lochhead, S. Ritter, J., \& Zhao, Q. (1996) "The cost of raising capital," Journal of Financial Research $19,59-74$

33. Liu, J., Uchida, K., \& Gao, R. (2012) "Political connections and the long term stock performance of Chinese IPOs," Journal of International Markets, Institutions and money 22 (4) 814-833.

34. Liu, W. (2010) "Liquidity risk and asset pricing: Evidence from daily data over 1926- 2008, " Working Papers (Nottingham University Business School)

35. Loughran, T. \& Ritter, J. (1995) "The new issues puzzle," Journal of Finance, 50, 23-51

36. Lowry, M., Officer, M. \& Schewert, G. (2008). The variability of IPOs Initial returns, Manuscript.

37. Lyon, J. D. Barber, B.M. \&Tsai, C.L. (1999) "Improved methods for tests of long-run abnormal stock returns," Journal of Finance, 54, 165-201.

38. McLean, R.D., Zhang, T, \& Zhao. M. (2011) "How do firms issue shares? Evidence from around the World," Working Papers University of Alberta

39. Merritt, C. (2017) Stock Market Turnover ratio. Economic Research Federal Reserve Bank of ST. Louis.

40. Minardi, A. M., Ferrariad, G.L., \& Araujo-Travares, P.C. (2013) "Performance of Brazilian IPO back by private equity," Journal of Business Research 66 (3) 448-455.

41. Mitchell, M.L. \& Stafford, E. (2000) "Managerial decisions and long-term price Performance," Journal of Business, 73, 287-329.

42. Pandey, I.M. (2015) Financial Management, $11^{\text {th }}$ Edition- New Delhi

43. Pontiff, J \& Schall, L.D. (1998) "Book to Market ratios as a predictor of market returns," Journal of Financial Economics 49 (10) 141-160.

44. Ritter, J. (1991 "The Long run performance of initial public," Journal of Finance 46, 3- 27

45. Schaub, M., \& Highfield, M. J. (2004) "Short term and Long term performance of

46. Silva, A., \& Bilinski, P. (2015) "Intended use of proceeds, underwriter quality and the long run performance of SEO in the UK." Journal of Business Finance and Accounting Vol. 42, 1282-1309

47. Slovin, M., Sushka, M. \& Lai, R. (2000) "Alternative Flotation Methods, Adverse Selection, and ownership Structures: Evidence from Seasoned Equity Issuance in UK" Journal of Financial Economics Vol.57 (2) 157-190

48. Spiess, D.K. \& Affleck- Graves, J. (1995) "Underperformance in long run stock returns following seasoned equity offerings," Journal of Financial Economics, 38, 243-26\%.

49. Su. C. \& Bangasa, K. (2011) "The impact of under writer reputation on initial returns and long run performance of Chinese IPOs," Journal of International Financial markets, Institutions and Money 18 (1) 117141.

50. Suzuki, K. \& Yamada, K. (2012) "Do the use of proceeds Disclosure and Bank Characteristics affect Bank underwriters Certification roles?" Journal of Business Finance and Accounting 39 (7-8)1102-1130.

51. Thomadakis, S. Nounis, C., \& Gounopoulas, D. (2012) "Long term performance of Greek IPOs," European Financial Management, Vol. 18, 1, 117-141.

52. Thomas, J., Jiao, Y. \&Yew, (2011) "Institutional Trading, Information Production and the SEO Discount: A model of Seasoned Equity Offerings", Journal of Economics and Management Strategy Vol. 20, 299-338.

53. Vithessonthi, C., \& Tongurai, J. (2015) "The effect of firm size on the leverage- performance relationship during the financial crisis of 2007-2009," Journal of Technology and Systems 1 (1) 18-39. 